\title{
ZAT HARA (FOSFAT, NITRAT), OKSIGEN TERLARUT DAN PH KAITANNYA DENGAN KESUBURAN DI PERAIRAN JIKUMERASA, PULAU BURU
}

\author{
(Nutriens (Phosphate, Nitrate), Dissolved Oxygen, and Dissolved pH \\ And They Relation to Productivity of Jikumerasa Waters, Buru Island)
}

\begin{abstract}
Simon I. Patty ${ }^{1^{*}}$, Hairati Arfah ${ }^{2}$, Malik S. Abdul ${ }^{2}$
1. UPT. Loka Konservasi Biota Laut Bitung-LIPI

2. Pusat Penelitian Laut Dalam Ambon-LIPI

*e-mail : pattysimon@ymail.com

The observation of nutrient content (phosphate, nitrate), dissolved oxygen and $\mathrm{pH}$ have been carried out in Jikumerasa waters, Buru Island in April 2014. The purpose of this study was to determine the water quality in terms of the content of nutrients that are indicators of productivity and their influencing factors. Phosphates and nitrates were analysed with spectrophotometric method using a UV-VIS spectrophotometer (Shimadzu 1700). Dissolved oxygen levels were determined with Winkler titration method and degree of acidity $(\mathrm{pH})$ was measured with pH meter (HANNA HI9024 series). The results indicated that phosphate levels ranging from 0.005 to $0.012 \mathrm{mg} / \mathrm{l}$, nitrate between from 0.013 to $0.015 \mathrm{mg} / \mathrm{l}$, dissolved oxygen between 5.57 to 5.96 and $\mathrm{pH} 7.65$ to 7.67 . The levels of phosphate, nitrate dissolved oxygen and $\mathrm{pH}$ value in Jikumerasa waters were classified as normal for water productivity and within the desirable range living organisms in the studied waters.
\end{abstract}

Keywords: Nutriens, Phosphate, Nitrate, Dissolved oxygen, Water productivity, Buru Island

Pengamatan zat hara (fosfat, nitrat), oksigen terlarut dan $\mathrm{pH}$ telah dilakukan di perairan Jikumerasa, Pulau Buru pada bulan April 2014. Tujuan penelitian ini untuk mengetahui kualitas air ditinjau dari kandungan zat hara yang merupakan indikator kesuburan perairan serta faktorfaktor yang mempengaruhinya. Analisa fosfat dan nitrat berdasarkan metoda spektrofotometri menggunakan spektrofotometer UV-VIS Shimadzu f1700. Kadar oksigen terlarut ditentukan dengan metoda titrasi Winkler dan derajat keasaman $(\mathrm{pH})$ diukur dengan $\mathrm{pH}$ meter HANNA seri HI9024. Hasilnya menunjukkan kadar fosfat berkisar antara 0,005-0,012 mg/l, nitrat antara 0,013-0,015 mg/l, oksigen terlarut antara 5,57-5,96 dan $\mathrm{pH}$ 7,65-7,67. Kadar fosfat, nitrat, oksigen terlarut dan nilai $\mathrm{pH}$ perairan Jikumerasa tergolong normal untuk kesuburan suatu perairan dan masih baik untuk kehidupan berbagai biota.

Kata kunci: Zat hara, Fosfat, Nitrat, Oksigen terlarut, Kesuburan perairan, Pulau Buru

\section{PENDAHULUAN}

Perairan Jikumerasa merupakan perairan yang sangat penting karena memiliki salah satu obyek pariwisata terkenal di Pulau Buru. Perairan ini relatif terbuka sehingga mudah dipengaruhi oleh massa air Laut Seram. Ditinjau dari letak geografisnya, perairan pantai Jikumerasa dan sekitarnya memiliki ekosistem estuary (muara sungai), mangrove, lamun, terumbu karang yang didalamnya dapat ditemukan berbagai jenis biota yang mempunyai nilai ekonomis. Selain itu terdapat sebuah danau (laguna) air laut. Interaksi antara danau dan laut sangat ditentukan oleh ambang yang sempit dan dangkal dalam mendukung kehidupan berbagai biota dan tumbuhan laut di dalamnya.

Keberadaan ekosistem yang kompleks, interaksi antara daratan dan lautan melalui aliran danau (laguna) 
dan aktivitas di sekitar perairan tersebut mempunyai pengaruh terhadap zat hara (fosfat dan nitrat), oksigen terlarut dan $\mathrm{pH}$ yang merupakan indikator kesuburan perairan. Fosfat dan nitrat merupakan zat hara yang penting bagi pertumbuhan dan metabolisme fitoplankton yang merupakan indikator untuk mengevaluasi kualitas dan tingkat kesuburan perairan (FerianitaFachrul et. al., 2005). Namun bila kedua zat ini konsentrasinya sangat besar di perairan dan melebihi nilai ambang batas maka terjadi eutrofikasi (pengayaan zat hara) yang ditandai dengan terjadinya blooming fitoplankton menyebabkan kematian berbagai jenis biota laut. Sumber utama zat hara fosfat dan nitrat berasal dari perairan itu sendiri yaitu melalui proses-proses penguraian pelapukan ataupun dekomposisi tumbuh-tumbuhan dan sisa-sisa organisme mati. Selain itu juga tergantung pada keadaan sekeliling diantaranya sumbangan dari daratan melalui aliran sungai yang terdiri dari berbagai limbah industri yang mengandung senyawa organik. Proses penguraian menjadi senyawa anorganik masuk ke perairan dalam proses banyak membutuhkan oksigen (Simanjuntak, 2012). Oksigen terlarut dalam air berasal dari hasil proses fotosintesis oleh fitoplankton atau tanaman air lainnya dan difusi dari udara (Bhatt dalam Andriani, 1999).

Oksigen terlarut dalam laut dimanfaatkan oleh organisme perairan untuk respirasi dan penguraian zat-zat organik oleh mikro-organisme. Menurunnya kadar oksigen terlarut di perairan menyebabkan terganggunya ekosistem perairan dan mengakibatkan semakin berkurangnya populasi biota.

Terganggunya suatu ekosistem perairan dapat diketahui dari kesuburan perairan dan indikator kesuburan perairan dapat dilihat dari keberadaan fosfat, nitrat, oksigen terlarut dan $\mathrm{pH}$. Fosfat dan nitrat dibutuhkan untuk mendukung organisme perairan terutama fitoplankton, sedangkan oksigen terlarut digunakan oleh organisme perairan dalam proses respirasi dan penguraian zat-zat organik oleh mikro-organisme. Derajat keasaman $(\mathrm{pH})$ suatu perairan merupakan salah satu parameter kimia yang penting dalam memantau kestabilan perairan. Secara alami keempat senyawa kimia ini terdapat dalam air laut pada kadar yang sesuai. Perubahan kadar yang terjadi tentu

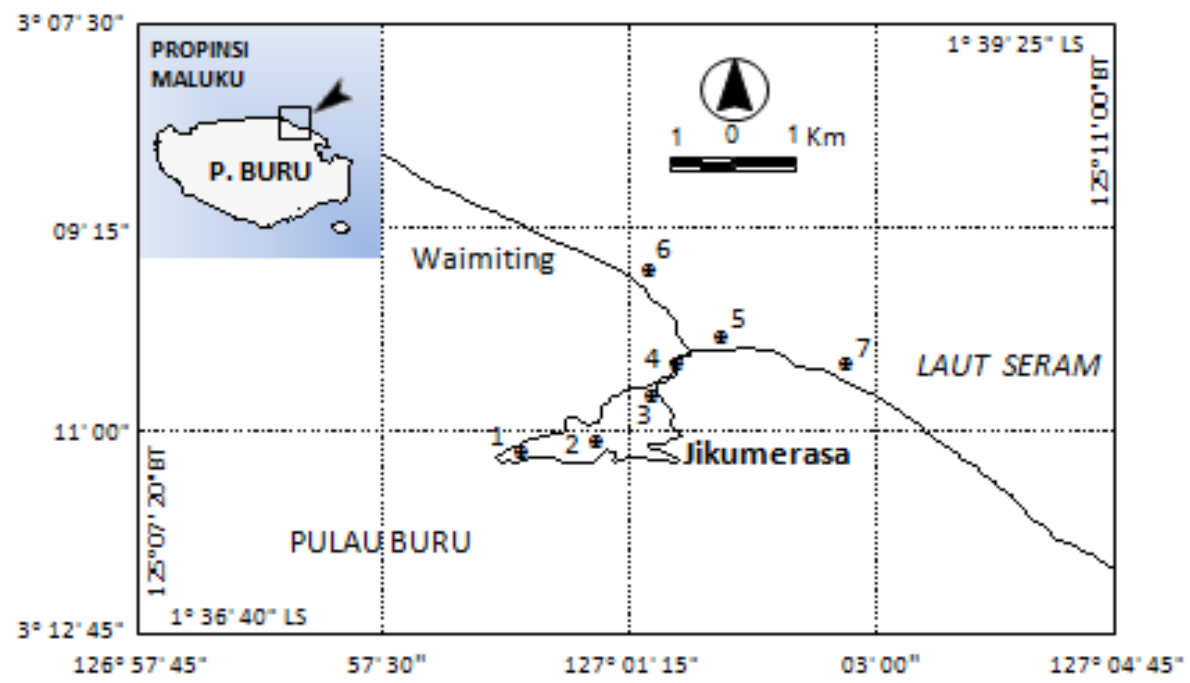

Gambar 1. Peta lokasi penelitian di perairan Jikumerasa, Pulau Buru. 
akan mempengaruhi kehidupan organisme yang hidup dalam perairan. Tulisan ini akan menguraikan tentang zat hara fosfat, nitrat, oksigen terlarut dan $\mathrm{pH}$ kaitannya dengan kesuburan di perairan Jikumerasa serta faktor-faktor yang mempengaruhinya.

Sampel air laut diambil dengan menggunakan tabung nansen pada lapisan permukaan dan dekat dasar. Analisa fosfat dan nitrat menurut Strickland \& Parsons (1968) berdasarkan metode spektrofotometri menggunakan spektrofotometer UV-VIS Shimadzu 1700. Kadar oksigen terlarut ditentukan berdasarkan metode titrasi Winkler. Sedangkan pengukuran $\mathrm{pH}$ air laut dilakukan secara in situ (langsung di lapangan) dengan memakai $\mathrm{pH}$ meter HANNA seri HI9024 yang telah dikalibrasi.

\section{HASIL DAN PEMBAHASAN}

Hasil pengukuran fosfat, nitrat, oksigen terlarut dan $\mathrm{pH}$ di perairan Jikumerasa, disajikan pada Tabel 1.

\section{Fosfat}

Kadar fosfat di lapisan permukaan berkisar antara 0,001-0,008 mg/l, kadar tertinggi diperoleh pada stasiun $1(0,008$ $\mathrm{mg} / \mathrm{l})$ dan terendah di stasiun $2(0,001$ $\mathrm{mg} / \mathrm{l})$. Untuk lapisan dekat dasar berkisar antara $0,005-0,027 \mathrm{mg} / \mathrm{l}$, kadar fosfat tertinggi terdapat di stasiun $2(0,027 \mathrm{mg} / \mathrm{l})$ dan terendah di stasiun $3(0,005 \mathrm{mg} / \mathrm{l})$. Konsentrasi fosfat baik di permukaan maupun dekat dasar perairan relatif berbeda (Gambar 2).

Kadar fosfat di perairan ini masih berada di bawah standar baku mutu. Disebutkan bahwa baku mutu konsentrasi fosfat yang layak untuk kehidupan biota laut dalam Keputusan Menteri Lingkungan Hidup, KLH (2004) adalah 0,015 mg/l. Data penelitian menunjukkan bahwa kadar fosfat di perairan ini berada di batas konsentrasi yang dipersyaratkan, sedangkan kadar fosfat yang lebih tinggi dari baku mutu berada di lapisan dekat dasar yaitu pada stasiun 1 dan 2 . Konsentrasi fosfat yang tinggi ini mungkin disebabkan tingginya difusi fosfat dari sedimen. Sedimen merupakan tempat penyimpanan utama fosfor dalam siklus yang terjadi di laut, umumnya dalam bentuk partikulat yang berikatan dengan senyawa hidroksida dan oksida besi. Senyawa fosfor yang terikat di sedimen dapat mengalami dekomposisi dengan bantuan bakteri maupun melalui proses abiotik menghasilkan senyawa fosfat

Tabel 1. Kadar Fosfat, Nitrat, Oksigen Terlarut dan pH di Perairan Jikumerasa

\begin{tabular}{|c|c|c|c|c|c|c|c|c|c|}
\hline \multirow{3}{*}{ Lokasi } & \multirow{3}{*}{ Stasiun } & \multicolumn{2}{|c|}{$\mathrm{PO} 4(\mathrm{mg} / \mathrm{l})$} & \multicolumn{2}{|c|}{ NO3 $(\mathrm{mg} / \mathrm{l})$} & \multicolumn{2}{|c|}{$\mathrm{DO}(\mathrm{mg} / \mathrm{l})$} & \multicolumn{2}{|c|}{$\mathrm{pH}$} \\
\hline & & \multicolumn{8}{|c|}{ Titik Sampling } \\
\hline & & $P$ & $\mathrm{D}$ & $P$ & D & $P$ & $\mathrm{D}$ & $P$ & $D$ \\
\hline \multirow{4}{*}{ Laguna } & 1 & 0,008 & 0,022 & 0,007 & 0,007 & 4,82 & 4,78 & 7,47 & 7,64 \\
\hline & 2 & 0,001 & 0,027 & 0,007 & 0,007 & 4,96 & 3,32 & 7,58 & 7,37 \\
\hline & 3 & 0,005 & 0,005 & 0,019 & 0,019 & 6,27 & 6,27 & 7,64 & 7,64 \\
\hline & 4 & 0,006 & 0,006 & 0,026 & 0,026 & 7,17 & 7,17 & 7,68 & 7,68 \\
\hline \multirow{3}{*}{ Jikumerasa } & 5 & 0,007 & 0,011 & 0,010 & 0,011 & 5,50 & 5,48 & 7,68 & 7,68 \\
\hline & 6 & 0,007 & 0,006 & 0,014 & 0,015 & 7,42 & 6,35 & 7,81 & 7,68 \\
\hline & 7 & 0,002 & 0,007 & 0,007 & 0,018 & 5,57 & 5,61 & 7,86 & 7,84 \\
\hline \multicolumn{2}{|c|}{ Min } & 0,001 & 0,005 & 0,007 & 0,007 & 4,82 & 3,32 & 7,47 & 7,37 \\
\hline \multicolumn{2}{|c|}{ Max } & 0,008 & 0,027 & 0,026 & 0,026 & 7,42 & 7,17 & 7,86 & 7,84 \\
\hline \multicolumn{2}{|c|}{ Rata-rata } & 0,005 & 0,012 & 0,013 & 0,015 & 5,96 & 5,57 & 7,67 & 7,65 \\
\hline
\end{tabular}

Keterangan: $P=$ Permukaan

$$
\mathrm{D}=\text { Dasar }
$$


Tabel 2. Tingkat Kesuburan Perairan berdasarkan Kadar Fosfat

\begin{tabular}{|c|c|}
\hline Fosfat $(\mathrm{mg} / \mathrm{l})$ & Tingkat Kesuburan \\
\hline $0-0,002$ & Kurang subur \\
$0,0021-0,050$ & Cukup subur \\
$0,051-0,100$ & Subur \\
\hline $0,101-0,200$ & Sangat subur \\
\hline$>0,201$ & Sangat subur sekali \\
\hline
\end{tabular}

Sumber : Joshimura dalam Wardoyo (1982)

terlarut yang dapat mengalami difusi kembali ke kolom air (Paytan and McLaughlin, 2007).

Fenomena ini dapat dipahami dengan melihat proses-proses yang terlibat di sekitar permukaan dasar perairan, karena stasiun 1 dan 2 merupakan perairan yang semi tertutup yang nyaris terisolasi dari perairan lepas pantai sehingga sirkulasi airnya kurang baik. Kondisi ini didukung oleh aktivitas masyarakat sekitarnya. Bisa dipastikan bahwa sumber utama penyumbang fosfat ke dalam teluk adalah limbah domestik masyarakat. Menurut WHO \& European Commision (2002), pengkayaan fosfor terutama berasal dari limbah rumah tangga dan industri, termasuk detergen berbahan dasar fosfor.

Secara umum kadar fosfat ratarata di perairan Jikumerasa berkisar antara 0,005-0,012 mg/l, menunjukkan bahwa perairan ini cukup subur. Joshimura dalam Wardoyo (1982) mengklasifikasikan tingkat kesuburan perairan yang cukup subur berdasarkan kadar fosfat berkisar antara 0,0021$0,050 \mathrm{mg} / \mathrm{l}$ dan perairan yang subur berkisar antara 0,051-0,100 mg/l (Tabel 2).

Menurut llahude dan Liasaputra (1980), kadar fosfat di lapisan permukaan pada perairan yang tersubur di dunia mendekati 0,6 ug.at/l atau setara dengan 0,019 $\mathrm{mg} / \mathrm{l}$. Klasifikasi kesuburan perairan ditinjau dari kadar fosfat menurut EPA (2002) adalah $<0,048 \mathrm{mg} / \mathrm{l}$ tergolong rendah, antara 0,048-0,096 $\mathrm{mg} / \mathrm{l}$ tergolong sedang, dan >0,096 $\mathrm{mg} / \mathrm{l}$ tergolong tinggi. Ketchum (1969) menetapkan suatu nilai fosfat sebesar 2,8 ug.at/l atau setara dengan $0,087 \mathrm{mg} / \mathrm{l}$ sebagai batas atas pada air yang tidak tercemar.

\section{Nitrat}

Kadar nitrat di perairan Jikumerasa beragam. Kadar nitrat lapisan permukaan maupun dekat dasar berkisar antara 0,007-0,026 mg/l. Kadar tertinggi di lapisan permukaan maupun dekat dasar terdapat di stasiun $4(0,026 \mathrm{mg} / \mathrm{l})$, sedangkan terendah di stasiun 1, 2 dan 7 (0,007 mg/l). Dari Gambar 2, terlihat bahwa konsentrasi nitrat sedikit lebih tinggi di dekat dasar perairan dibandingkan dengan lapisan permukaan. Kondisi ini mungkin disebabkan kadar nitrat di lapisan permukaan lebih banyak dimanfaatkan atau dikonsumsi oleh fitoplankton. Selain itu kadar nitrat yang sedikit lebih tinggi di dekat dasar perairan juga dipengaruhi oleh sedimen. Sedimen merupakan tempat penyimpanan utama nitrat dalam siklus yang terjadi di laut. Menurut Seitzinger (1988), nitrat yang berada di dalam sedimen diproduksi dari biodegradasi bahan-bahan organik menjadi ammonia yang selanjutnya dioksidasi menjadi nitrat.

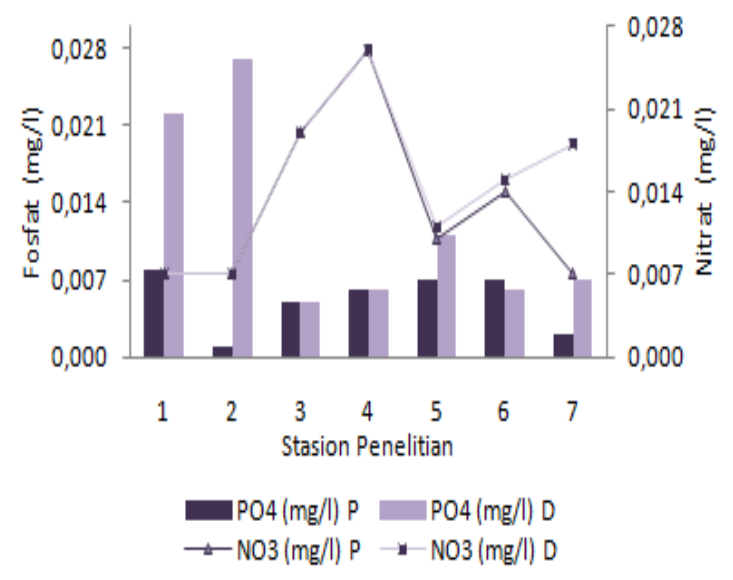

Gambar 2. Distribusi fosfat dan nitrat lapisan permukaan $(\mathrm{P})$ dan dekat dasar (D) di perairan Jikumerasa. 
Tabel 3. Hubungan Kandungan Nitrat dengan Pertumbuhan Organisme

\begin{tabular}{|c|c|}
\hline Nitrat $(\mathrm{mg} / \mathrm{l})$ & $\begin{array}{c}\text { Pertumbuhan } \\
\text { Organisme }\end{array}$ \\
\hline $0,3-0,9$ & Cukup \\
\hline $0,9-3,5$ & Optimum \\
$>3,5$ & $\begin{array}{c}\text { Membahayakan } \\
\text { perairan }\end{array}$ \\
\hline
\end{tabular}

Sumber : Chu dalam Wardoyo (1982)

Konsentrasi nitrat rata-rata yang diperoleh di perairan ini berkisar antara 0,013-0,015 mg/l. Secara umum kadar nitrat ini masih tinggi di atas kandungan nitrat yang umum dijumpai di perairan laut. Kadar nitrat yang normal di perairan laut umumnya berkisar antara $0,10-0,50 \mu \mathrm{g} . \mathrm{at} / \mathrm{l}$ atau setara dengan 0,001-0,007 mg/l (Brotowidjoyo et al. 1995). Kadar nitrat ini juga masih baik untuk pertumbuhan karang. Kadar nitrat di perairan ekosistem terumbu karang di Eri (Teluk Ambon) yang kondisi karangnya termasuk kategori sangat baik berkisar antara 0,22-5,10 $\mu \mathrm{g}$.at/l atau 0,003-0,071 mg/l (Sutarna, 1987). Adapun hubungan antara kadar nitrat dan pertumbuhan organisme nabati (Chu dalam Wardoyo, 1982) dapat di lihat pada Tabel 3. Disebutkan bahwa baku mutu konsentrasi nitrat yang layak untuk kehidupan biota laut dalam Keputusan Menteri Lingkungan Hidup, KLH (2004) adalah 0,008 mg/l.

Hasil pengamatan menunjukkan bahwa hanya stasiun 1 dan 2 baik di lapisan permukaan maupun dekat dasar yang kadarnya berada di batas konsentrasi yang dipersyaratkan. Sedangkan kadar nitrat yang lebih tinggi dari baku mutu baik di lapisan permukaan maupun di lapisan dekat dasar sebarannya hampir merata, terkecuali stasiun 7 di lapisan permukaan yang kadarnya masih berada di batas konsentrasi yang dipersyaratkan. Rendahnya kadar nitrat pada stasiun 1 dan 2 diduga karena kurang mendapat masukan (run-off) dari lahan pertanian yang pada umumnya banyak mengandung nitrat. Menurut WHO \& European Commision (2002), sumber utama pengkayaan nitrogen adalah run-off yang berasal dari lahan pertanian. Nilai ambang batas suatu perairan yang ditetapkan US-EPA (1973) untuk nitrat sebesar $0,07 \mathrm{mg} / \mathrm{l}$. Dengan demikian kadar nitrat di perairan Jikumerasa masih dalam batas aman kesuburan suatu perairan.

\section{Oksigen Terlarut}

Kadar oksigen terlarut dalam air permukaan berkisar antara 4,82 - 7,42 $\mathrm{mg} / \mathrm{l}$ dan dekat dasar berkisar antara 3,32 - 7,17 mg/l. Kadar oksigen terlarut terendah dijumpai di stasiun 1 dan 2 yaitu nilainya < $5 \mathrm{mg} / \mathrm{l}$ (Gambar 3). Rendahnya kadar oksigen terlarut di stasiun 1 dan 2 (terletak di dalam laguna) berkaitan erat dengan tingginya kekeruhan air di lokasi tersebut dan juga mungkin disebabkan oleh semakin meningkatnya aktivitas mikro organisme dalam menguraikan zat organik menjadi zat anorganik yang menggunakan oksigen terlarut. Menurut Wardhana (2001), pada lapisan dasar perairan terjadi akumulasi bahan organik yang membutuhkan oksigen dalam proses penguraiannya. Semakin banyak bahan buangan organik yang ada di dalam air, semakin sedikit sisa kandungan oksigen yang terlarut di dalamnya. Kecenderungan menurunnya oksigen terlarut di perairan ini sangat dipengaruhi oleh meningkatnya bahan-bahan organik yang masuk ke perairan disamping faktor-faktor lainnya diantaranya kenaikan suhu, salinitas, respirasi, adanya lapisan di atas permukaan air, senyawa yang mudah teroksidasi dan tekanan atmosfir (Reid, 1961; Welch, 1980 dalam Simanjuntak, 2007). Sedangkan nilai oksigen terlarut di beberapa stasiun penelitian masih sesuai dengan baku mutu air laut, Keputusan Menteri Lingkungan Hidup, $\mathrm{KLH}$ (2004) yaitu $\geq 5 \mathrm{mg} / \mathrm{l}$. Kadar oksigen terlarut di dalam massa air 
Tabel 4. Kriteria Kualitas Air berdasarkan Kadar Oksigen Terlarut

\begin{tabular}{|c|c|}
\hline $\begin{array}{c}\text { Oksigen terlarut } \\
(\mathrm{mg} / \mathrm{l})\end{array}$ & Kriteria \\
\hline$>6,5$ & Tidak tercemar \\
\hline $4,5-6,4$ & Tercemar ringan \\
\hline $2-4,4$ & Tercemar sedang \\
\hline$<2$ & Tercemar berat \\
\hline Sumber : Lee et. al. (1978)
\end{tabular}

nilainya adalah relatif, biasanya berkisar antara 6-14 ppm (Connel and Miller, 1995).

Secara umum kadar oksigen terlarut rata-rata di perairan Jikumerasa berkisar antara 5,57 - 5,96 mg/l, bila dibandingkan dengan kriteria kualitas air, termasuk pada kriteria tercemar ringan (Tabel 4).

Kadar oksigen di perairan laut yang tercemar ringan adalah $5 \mathrm{mg} / \mathrm{l}$ (Sutamihardja, 1987). Rivai (1983) mengatakan bahwa pada umumnya kandungan oksigen sebesar $5 \mathrm{mg} / \mathrm{l}$ dengan suhu air berkisar antara $20-30^{\circ} \mathrm{C}$ relatif masih baik untuk kehidupan ikan-ikan, bahkan apabila dalam perairan tidak terdapat senyawasenyawa yang bersifat toksik (tidak tercemar) kandungan oksigen sebesar $2 \mathrm{mg} / \mathrm{l}$ sudah cukup untuk mendukung kehidupan organisme perairan (Swingle dalam Salmin, 2005).

\section{Derajat Keasaman (pH)}

Derajat keasaman $(\mathrm{pH})$ dalam air laut permukaan berkisat antara antara 7,47 - 7,86 dan dekat dasar berkisar antara antara 7,37 - 7,84. Nilai ini masih di bawah $\mathrm{pH}$ normal perairan. Menurut Salm (1984), pH di suatu perairan yang normal berkisar antara 8,0-8,3. Secara umum air laut relatif lebih alkali (basa) sekitar 8.0. akan tetapi organisme air laut relatif mampu beradaptasi dengan ruang $\mathrm{pH}$ yang lebar (Udi at. al., 2011).

Gambar 3 memperlihatkan nilai $\mathrm{pH}$ yang diperoleh di permukaan maupun dekat dasar relatif sama. Hasil

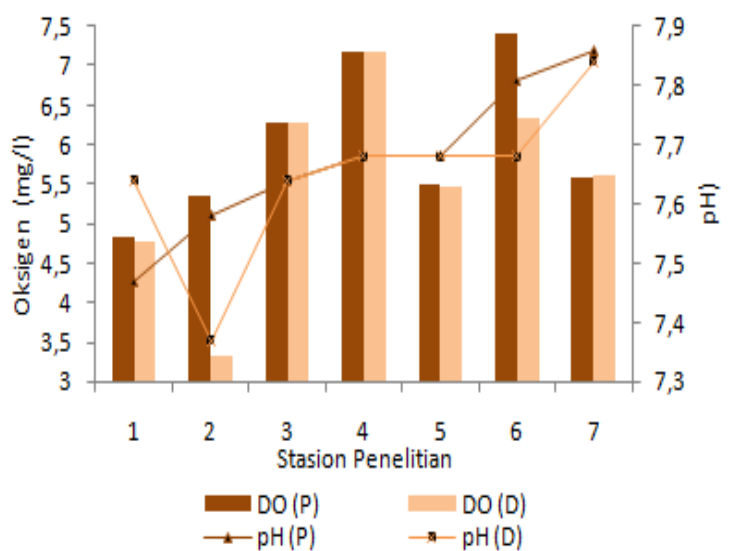

Gambar 3. Distribusi oksigen terlarut dan $\mathrm{pH}$ lapisan permukaan (P) dan dekat dasar (D) di perairan Jikumerasa.

pengukuran rata-rata derajat keasaman $(\mathrm{pH})$ berkisar antara 7,65-7,67 dan bila dilihat dari standar baku mutu, maka nilai $\mathrm{pH}$ yang diperoleh tidak melebihi standar baku mutu yang ditetapkan menurut Keputusan Menteri Lingkungan Hidup, KLH (2004) yaitu 7 8,5. Perairan dengan kisaran $\mathrm{pH}$ antara 7 - 8,5 merupakan daerah yang potensial sebagai tempat budidaya dan rekreasi. Besarnya nilai $\mathrm{pH}$ air laut di perairan ini masih baik untuk kepentingan terumbu karang. Nilai $\mathrm{pH}$ yang baik untuk terumbu karang berkisar antara 6-9 (Edward dan Tarigan, 2003). Pescod dalam Susana (2005) memberikan batasan $\mathrm{pH}$ yang ideal bagi biota laut nilainya berkisar antara 6,5 - 8,5; sedangkan EPA (1973) menetapkan kisaran $\mathrm{pH}$ 6,5 - 8,5 untuk perikanan.

\section{KESIMPULAN}

Kadar fosfat dan nitrat di perairan Jikumerasa umumnya bervariasi dimana di dekat dasar lebih tinggi dibandingkan dengan lapisan permukaan. Sedangkan oksigen terlarut dan $\mathrm{pH}$ di lapisan permukaan maupun di lapisan dekat dasar perairan relatif sama. Bila ditinjau dari zat hara (fosfat dan nitrat), oksigen terlarut dan $\mathrm{pH}$ yang merupakan indikator 
kesuburan perairan, maka perairan Jikumerasa termasuk subur, masih baik untuk kehidupan biota laut dan untuk berbagai kepentingan sesuai dengan kriteria yang ditetapkan oleh Kementerian Negara Lingkungan Hidup.

\section{DAFTAR PUSTAKA}

Andriani, E.D. 1999. Kondisi FisikaKimiawi Air Perairan Pantai Sekitar Tambak Balai Budidaya Air Payau (BBAP) Jepara, Kabupaten Jepara, Jawa Tengah. Skripsi. Fakultas Perikanan dan IImu Kelautan, Institut Pertanian Bogor.

Brotowidjoyo, D.M., Tribowo, D., Eko. M. 1995. Pengantar Lingkungan Perairan dan Budidaya Air. Liberty, Yogyakarta. 87 hal.

Connel, W.D., Miller, G.J. 1995. Kimia dan

Ekotoksikologi Pencemaran. Terjemahan. Penerbit Universitas Indonesia: 520 hal.

Edward, Tarigan, Z. 2003. Pemantauan kondisi hidrologi diperairan Raha P. Muna, Sulawesi Tenggara Dalam Kaitannya Dengan Kondisi Terumbu Karang. Makara, Sains, Vol. 7 (2): 73-82.

Environmental Protection Agency (EPA). 2002. Water Quality Criteria. Mid-Atlantic Integrated Assessment (MAIA) Estuaries. USA. Ecological Research Series Washington: 595 pp.

Ferianita-Fachrul, M., Haeruman, H., Sitepu, L.C. 2005. Komunitas Fitoplankton sebagai BioIndikator Kualitas Perairan Teluk Jakarta. Seminar Nasional MIPA 2005. FMIPAUniversitas Indonesia, 24-26 November 2005. Jakarta.

llahude, A.G., Liasaputra. 1980. Sebaran normal parameter hidrologi di Teluk Jakarta. Dalam : Nontji, A., Djamali, A. (Editor). Teluk Jakarta. Penyajian Fisika, Kimia, Biologi dan Geologi. LON-LIPI : 1-40.

Kementerian Lingkungan Hidup Republik Indonesia (KLH). 2004. Baku mutu air laut untuk biota laut. Keputusan Menteri Negara Lingkungan Hidup No.51 Tahun 2004 Tentang Baku Mutu Air Laut. KLH. Jakarta.

Ketchum, D.H. 1969. Eutrophication of estuaries. In: Eutrophication Causes, Consequences, Corrective National Academy of Sciences, Washington, D.C. 197-209pp.

Paytan, A.\& K. McLaughlin 2007. The Oceanic Phosphoru s Cycle. Chem. Rev., 107(2): 563-576.

Riva'i, R.S., Pertagunawan, K.. 1983. Biologi Perikanan I, Penerbit CV. Kayago, Jakarta, 143 hal.

Salm, R.V. 1984. Coral Reef Management Handbook. Unesco-Rostrea, Jakarta, p. 15.

Salmin. 2005. Oksigen Terlarut (DO) dan Kebutuhan Oksigen Biologi (BOD) Sebagai Salah Satu Indikator Untuk Menentukan Kualitas Perairan. Oseana, Vol.XXX (3): 21 - 26.

Seitzinger, S.P. 1988. Denitrification in Freshwater and Marine Coastal Ecosystems : Ecological and geochemical significance. Limnol. Oceanogr. 33(4, Part 2): 702-724.

Simanjuntak, M. 2007. Oksigen Terlarut dan Apparent oxygen Utilization di Perairan Teluk Klabat, Pulau Bangka. Dalam : Ilmu Kelautan UNDIP. Vol 12 (2) : 59-66.

Simanjuntak, M. 2012. Kualitas air laut ditinjau dari aspek zat hara, oksigen terlarut dan $\mathrm{pH}$ di perairan Banggai, Sulawesi 
Tengah. Jurnal IImu dan Teknologi Kelautan Tropis. Vol.4 (2): 290-303.

Strickland, J.D.H., Parsons, T.R. 1968. Determination of dissolved oxygen. In: Stevenson, J.C.,. Billingsley, L.W., Wigmore, R.H., Mac intyre, R.L., Glassford, M., Skulski, M. (Eds). A practical Handbook of Seawater Analysis. Fish. Res. Board Can: 21-26.

Susana, T. 2005. Kualitas Zat Hara Perairan Teluk Lada, Banten. Oseanologi dan Limnologi di Indonesia. 59 - 67.

Sutamiharja, R.T.M. 1987. Kualitas dan Pencemaran Lingkungan.

Fakultas Pascasarjana, Institut Pertanian Bogor. 92 hal.

Sutarna, I.N. 1987. Keanekaragaman dan Kekayaan Jenis Karang Batu di Teluk Ambon Bagian Luar, Pulau Ambon, Buku Teluk Ambon (Biologi, Perikanan, Oseanografi dan Geologi). BSDL LIPI Ambon, Ambon, 1987. 9 hal.

Udi, Putra, Nana, S.S. 2011. Manajemen Kualitas Air Pada Kegiatan Perikanan Budidaya. Departemen Kelautan dan Perikanan Direktorat Jendral Perikanan Budidaya Balai Budidaya Air Payau Takalar.

US Environmental Protection Agency. 1973. Water Quality Criteria 1972, EPA-R3-73-033-March 1973. p177

Wardhana, W.A. 2001. Dampak Pencemaran Lingkungan (Edisi revisi). Penerbit Andi. Yogyakarta.

Wardoyo, S.T.H. 1982. Water Analysis Manual Tropical Aquatic Biology Program. Biotrop, SEAMEO. Bogor. 81 hal.

World Health Organization and European Commission. 2002.
Eutrophication and Health. Edited by K. Pond. Luxembourg: Office for official Publication of the European communities. p 28. 